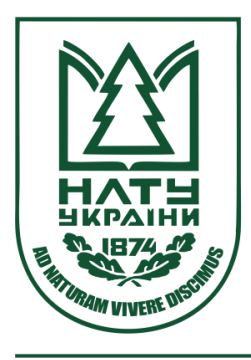

Науковий вісник НЛТУ України Scientific Bulletin of UNFU http://nv.nltu.edu.ua

https://doi.org/10.15421/40290304

$@ \bowtie$ Correspondence author

Article received 15.04.2019 p.

Article accepted 25.04.2019 p.

E. A. Fedoruk

УДК 712.[42+253]

Національний університет біоресурсів і природокористування України, м. Київ, Україна

\title{
ЖИВИЙ НАДГРУНТОВИЙ ПОКРИВ ЯК ІНДИКАТОР СТАНУ ЛІСОПАРКОВИХ МАСИВІВ
}

Наведено результати досліджень живого надгрунтового покриву зон відпочинку лісопаркових масивів Києва. Охарактеризовано зміни живого надгрунтового покриву, що зумовлені збілышенням рекреаційного навантаження та розвитком лісопаркових ценозів, оскільки в разі змін у рекреаційному навантаженні першими на це реагують трав'яні рослини, лишайники та мохи. Відповідно до поставленої мети досліджено стан та проаналізовано склад живого надгрунтового покриву в рекреаційних зонах лісопарків Києва. Визначено фактичні, оптимальні та граничні рекреаційні навантаження та рекреаційні місткості досліджуваних зон відпочинку лісопарків Києва, що характеризують їх природний рекреаційний потенціал. Оцінено вплив рекреаційного навантаження на лісопаркові масиви. Встановлено, що в зонах відпочинку міста відбувається нерівномірний розподіл відвідувачів лісопарків, що призводить до знищення характерних трав'яних лісових рослин та незворотних змін у живому надгрунтовому покриві. Розглянуто основні причини, що сприяли розвитку цього явища. Встановлено, що на сьогодні $\epsilon$ потреба в застосовуванні системи заходів, спрямованих на зниження рекреаційних навантажень у зонах масового відпочинку, їх збереження, ефективне використання та охорону територій, а також потрібно підвищити якість благоустрою територій, де $є$ високий рівень рекреаційних навантажень.

Ключові слова: стадії дигресії; рекреаційне навантаження; зони відпочинку; лісопаркові ценози; трав'яні рослини.

Вступ. Нині постійна динаміка зміни рекреаційних навантажень та масштаби іiі впливу на зелені насадження лісопаркових територій зумовлює необхідність постійного контролю з боку науковців, задля уникнення та попередження незворотних руйнівних процесів у біогеоценозах. Живий надгрунтовий покрив $є$ першою ланкою в лісовому середовищі, котра потерпає зі збільшенням антропогенного впливу на неї, тому аналіз його стану є важливим у дослідженні цього питання.

Стан живого надгрунтового покриву в лісі досліджувало багато вчених. Сукцесії трав'яного покриву на лісових землях є індикатором змін, які відбуваються в лісовому господарстві внаслідок дії різних чинників (Hordiienko et al., 2007). Склад і кількість лісового живого надгрунтового покриву можуть слугувати інтегрованим критерієм для оцінення лісівничого потенціалу лісових ділянок та екологічності як окремих лісогосподарських заходів, так і певних комплексів лісогосподарських робіт з відтворення лісу, догляду за ними та їх захисту (Maurer \& Pinchuk, 2010). I. В. Іванюк досліджував живий надгрунтовий покрив у зеленій зоні Кисва (Ivaniuk, 2009). Живий надгрунтовий покрив на техногенно порушених землях після стихійного видобутку бурштину вивчав проф. С. Б. Ковалевський (Kovalevsky et al., 2017), М. I. Гордієнко, В. В. Озадовський досліджували сукцесії живого надгрунтового покриву лісових земель Полісся та Лісостепу (Hordiienko et al., 2007).

Основна мета роботи - вивчити та визначити стан живого надгрунтового покриву в рекреаційних зонах Києва. Визначити коефіцієнт рекреації в зонах відпо- чинку та стадії рекреаційної дигресії. Визначити середні значення рекреаційних навантажень, рекреаційну місткість та оцінити рекреаційний потенціал лісопарків Києва.

Матеріали та методика дослідження. Дослідження проводили на території КП "Дарницьке ЛПГ", КП "Святошинське ЛПГ" та КП "ЛПГ "Конча-Заспа" м. Києва. Для визначення площ лісів, придатних для рекреації, а також деяких інших показників використано матеріали останнього лісовпорядкування для кожного господарства.

Для визначення таксаційних показників рекреаційного призначення (Kutia \& Hirs, 2012) та розрахунку рекреаційних навантажень і місткості природних комплексів використано методику, яку запропонував Р. Р. Возняк (Hensyruk et al., 1987). Згідно з цією методикою, для визначення фактичних рекреаційних навантажень лісопарків Києва було закладено 5 облікових пробних площ у насадженнях, що є найхарактернішими для умов досліджуваної території, на яких здійснено облік відвідуваності. Під час обліку відвідуваності заповнювали спеціальну відомість, куди вносили щогодинні дані кількості людей, що увійшли і вийшли з об'єкта спостережень, а також людей, які не вийшли у конкретний час (щогодинну різницю між сумами накопичених підсумків за графами "увійшло" і "вийшло"). Спостереження проводили у будній та вихідний дні.

Значення рекреаційного навантаження на 1 га лісопарку в день обліку визначали за такою формулою:

$$
n_{d}=\frac{A_{1}+A_{2}}{t_{d} \cdot S}
$$

\section{Інформація про авторів:}

Федорук Еліна Анатоліївна, аспірант, кафедра відтворення лісів та лісових меліорацій. Email: elinafedoruk@gmail.com Цитування за ДСтУ: Федорук Е. А. Живий надґрунтовий покрив як індикатор стану лісопаркових масивів. Науковий вісник НЛтУ України. 2019, т. 29, № 3. С. 23-26.

Citation APA: Fedoruk, E. A. (2019). Living ground cover as an indicator of the state of forest park massives. Scientific Bulletin of UNFU, 29(3), 23-26. https://doi.org/10.15421/40290304 
де: $n_{d}$ - рекреаційне навантаження в день обліку, люд. дн. $^{-1} \cdot$ га $^{-1} ; A_{1}-$ кількість рекреантів, що увійшла у лісовий масив, люд.; $A_{2}$ - загальна кількість рекреантів, що не вийшла у конкретний час, люд.; $t_{d}-$ тривалість умовного облікового дня (в нашому випадку 8 год), год; $S$ - площа лісового масиву, га (Kutia \& Hirs, 2012).

Для визначення середнього показника рекреаційного навантаження загалом для всіх трьох лісопаркових господарств використано другий спосіб, що передбачає використання відомостей про лісорекреаційну активність населення в межах досліджуваної території. Лісорекреаційна активність полягає у кількості годин, яку проводить одна людина в лісі впродовж року. Вона залежить від населення міста і визначено іiі за формулою А. I. Тарасова (Tarasov, 1986)

$$
a=1,1 \cdot P^{0,3},
$$

де: $a$ - лісорекреаційна активність мешканця міста, год; $P$ - кількість населення міста, осіб.

Величину рекреаційного навантаження на 1 га, що створюють жителі міста, визначали за формулою

$$
n=\frac{a \cdot P}{t_{d} \cdot D \cdot S},
$$

де: $n$ - середнє рекреаційне навантаження на рекреаційні ліси, люд./дн./га; $a$ - лісорекреаційна активність одного мешканця міста за комфортний період, год; $P$ населення міста, осіб; $t_{d}$ - тривалість умовного облікового дня, год; $D$ - тривалість комфортного періоду (для наших умов 210 днів), днів; $S$ - загальна площа лісів, придатних для рекреаційного використання, га.

Розрахунок оптимальної та граничної місткості виконано за формулою

$$
E=\sum_{i=1}^{k} n_{i}^{\max } \cdot S_{i},
$$

де: $E$ - екологічно допустима (оптимальна чи гранична) рекреаційна місткість, люд./дн.; $n_{i}^{\max }$ - оптимальне чи граничне рекреаційне навантаження, що призводить природні комплекси до другої чи третьої стадій дигреciї, люд./дн./га; $S_{i}$ - площа $i$-тої ділянки лісу певного класу стійкості, га.

Стадії рекреаційної дигресії визначали за коефіцієнтом рекреації $(K p)$, який розраховували за відношенням площі ущільненої й витоптаної поверхні ділянки до їі загальної площі. Його виражали у долях одиниці із заокругленням до сотих (Vozniak \& Fukorevych, 2000).

Результати дослідження. Як відомо, комплекс чинників, що впливають на біологічну стійкість лісових ценозів, поділяють на три групи: біотичні, абіотичні та антропогенні. Найбільшого впливу на біологічну стійкість лісопаркових ценозів завдають антропогенні чинники (Hensyruk et al., 1987).

Нині зі збільшенням населення в Києві відбувається стрімке зростання інтенсивності рекреації, особливо в лісових та прибережних зонах рекреації, тобто збільшився антропогенний вплив на природні біогеоценози. Збільшення рекреаційного навантаження зумовлює незворотні зміни водно-фізичних властивостей грунту та порушення його структури, що слугує однією $з$ основних причин зникнення деяких видів рослин та сукцесій трав'яного покриву (Krasnov et al., 2012).

Рекреаційні навантаження завдають найбільшого впливу на нижні горизонти рослинності - трав'яні види, мохи та лишайники. Зникнення видів трав'яних рослин призводить до порушення біогеохімічних циклів, створення умов нестачі мінерального живлення для деревних порід (Krasnov et al., 2012). Для визначення рекреаційного потенціалу лісів потрібно встановити площі лісових ділянок, що придатні для ведення на них рекреаційної діяльності, та відповідні їм рекреаційні навантаження, а також величину рекреаційної місткості цих лісів (Kutia \& Hirs, 2012).

Більшості зонам відпочинку характерні друга та третя стадії дигресії. Живий надгрунтовий покрив, окрім характерних трав'яних лісових рослин, має багато представників, характерних для лугів: буквиця лікарська, снить звичайна, костриця лучна, фіалка та ін. У місцях біля пішохідних доріжок присутні конюшина біла, подорожник ланцетолистий, кульбаба, конюшина червона, котрі утворюють щільний покрив в цих місцях. Через нерівномірний розподіл відвідувачів у межах однієї зони відпочинку можна спостерігати як другу, так i п'яту стадії дигресії. Особливо це помітно в зонах відпочинку, де благоустрій території займає дуже малу територію від іï загальної площі. Яскравим прикладом такого явища слугує зона відпочинку "Веселка", що розташована біля Броварського проспекту.

Ступінь дигресії безпосередньо залежить від рекреаційних навантажень та стійкості природних компонентів до них. Тому залежно від порушення природних умов встановлюють стадію дигресії. Під час натурного обстеження зон відпочинку встановлювали коефіцієнт рекреації, котрий визначали за відношенням ущільнених та витоптаних поверхонь до загальної площі ділянки (Hensyruk et al., 1987). Результати досліджень наведено у табл. 1.

Результати визначення фактичного рекреаційного навантаження на пробних площах, а також відповідних оптимальних і гранично допустимих для цих ділянок навантажень (відповідно до рекомендацій Р. Р. Возня-

\begin{tabular}{|c|c|c|c|c|}
\hline Назва зони відпочинку & Площа урочища, га & Коефіцієнт рекреації & Стадія дигресії & Благоустрій \\
\hline 1 & 2 & 3 & 4 & 5 \\
\hline \multicolumn{5}{|c|}{ Броварське лісництво } \\
\hline Пухівська & 68 & 0,1 & 2 & Столи, лави \\
\hline Калинівка & 86 & 0,2 & 3 & Кв. 49, вид. 3 столи, стільці \\
\hline Березовий гай & 144 & 0,5 & 4 & Кв. 72, вид. 33 столи, стільці \\
\hline Зелена галявина & 1 & 0,1 & 3 & $\begin{array}{l}\text { Укриття від негоди, обладнано місце відпо- } \\
\text { чинку, самозахоплення приватними особами }\end{array}$ \\
\hline \multicolumn{5}{|c|}{ Білодібровне лісництво } \\
\hline Біла діброва & 148 & 0,2 & 3 & Столи, лави \\
\hline Придорожня & 35 & 0,3 & 3 & Столи, лави \\
\hline \multicolumn{5}{|c|}{ Дніпровське лісництво } \\
\hline Веселка & 253 & 0,65 & 5 & Столи, лави \\
\hline Берізка & 107 & 0,6 & 4 & Столи, лави, стільці, укриття від дощу \\
\hline
\end{tabular}
ка) наведено в табл. 2.

Табл. 1. Стисла характеристика зон відпочинку м. Києва за показниками рекреації 


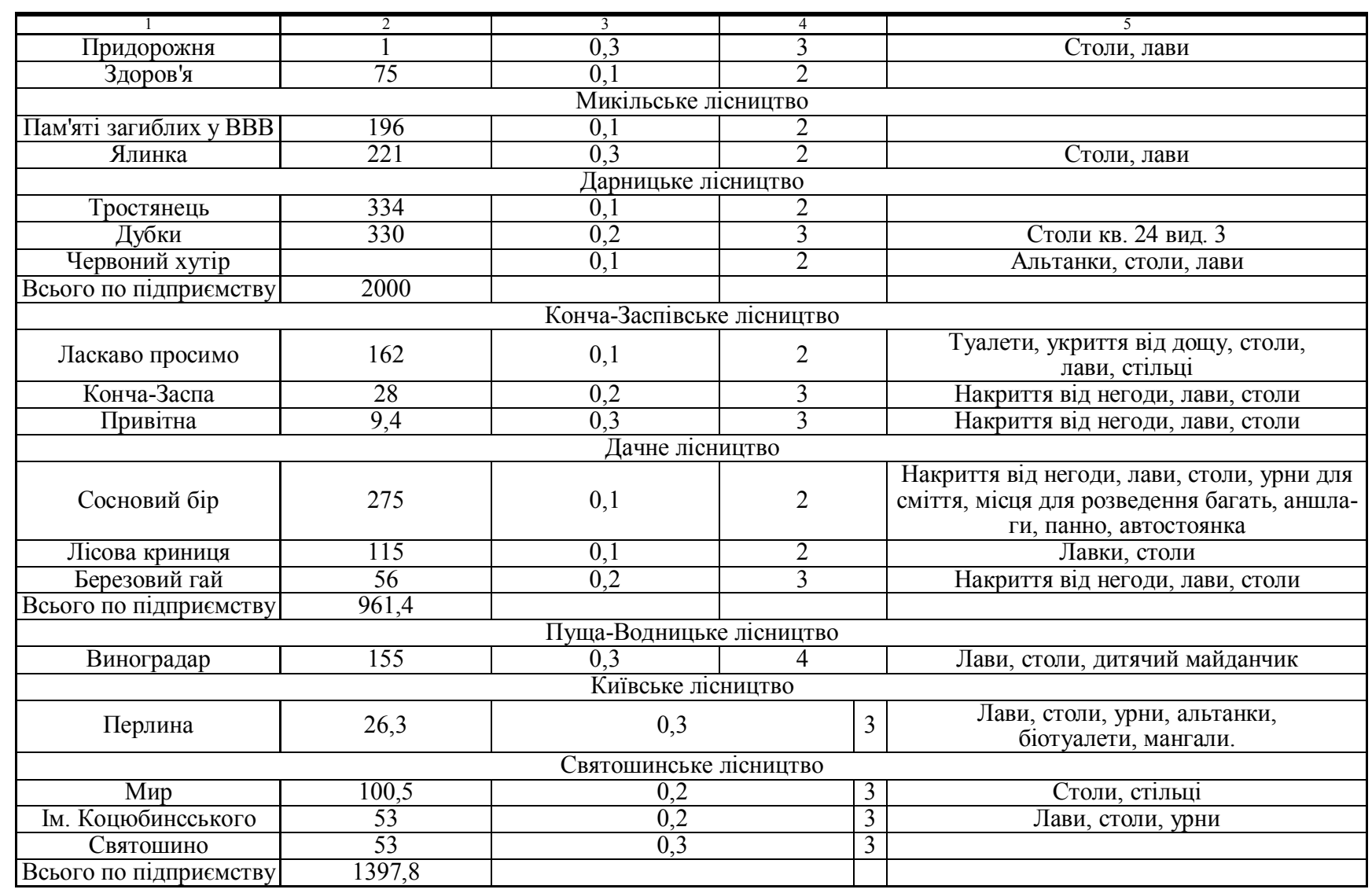

Табл. 2. Фактичні, оптимальні та гранично допустимі рекреаційні навантаження лісопаркових ландшафтів м. Кисва

\begin{tabular}{|c|c|c|c|c|c|c|c|}
\hline \multirow{2}{*}{$\begin{array}{l}\text { № } \\
\text { 3/ח }\end{array}$} & \multirow{2}{*}{ Місце розташування пробної площі } & \multicolumn{2}{|c|}{$\begin{array}{l}\text { Рекреаційна характе- } \\
\text { ристика пробної площі }\end{array}$} & \multicolumn{4}{|c|}{ Рекреаційне навантаження, люд. ·н.-1·га-1 } \\
\hline & & $\begin{array}{c}\text { стадія } \\
\text { дигресії }\end{array}$ & $\begin{array}{c}\text { клас } \\
\text { стійкості }\end{array}$ & $\begin{array}{c}\text { фактичне } \\
(2012)^{*}\end{array}$ & $\begin{array}{c}\text { фактичне } \\
\text { (2018) }\end{array}$ & оптимальне & граничне \\
\hline 1 & Дарницьке ЛПГ, Дніпровське л-во, кв. 25 & 1 & 2 & 2,71 & 2,90 & 4,0 & 12,0 \\
\hline 2 & Святошинське ЛПГ, Пуща-Водицьке л-во, кв 46 & 1 & 2 & 0,70 & 0,70 & 4,0 & 12,0 \\
\hline 3 & Святошинське ЛПГ, Пуща-Водицьке л-во, кв. 143 & 3 & 3 & 7,33 & 7,46 & 2,5 & 7,5 \\
\hline 4 & |ЛПГ "Конча-Заспа", Голосіївське л-во, кв. 4 & 2 & 2 & 6,18 & 6,25 & 4,0 & 12,0 \\
\hline 5 & |ЛПГ "Конча-Заспа", Голосіївське л-во, кв. 10 & 2 & 2 & 2,85 & 2,90 & 4,0 & 12,0 \\
\hline
\end{tabular}
Примітка: * - Hordiienko et al, 2007

За даними табл. 2 видно, що рекреаційне навантаження на чотирьох дослідних ділянках близьке до оптимального та не перевищує гранично допустимого навантаження. Виняток становить третя пробна площа, де показник рекреаційного навантаження максимально наближений до граничного. Помітна тенденція до збільшення рекреаційного навантаження за останні шість років.

Згідно зі статистичними даними на 1. 09. 2018 р., населення Києва становить 2937531 осіб, звідси лісорекреаційна активність становить 86 год/рік. Користуючись матеріалами останнього лісовпорядкування, за кожним лісопарковим господарством визначено загальну площу, що використовують для рекреації (ліси, що входять до зон масового відпочинку, інтенсивної та екстенсивної рекреації, а також зони регульованої рекреації, тобто без зон природних резервантів та інших непридатних до рекреації ділянок), яка становить 27805,6 га. За формулою (3) обчислено середнє рекреаційне навантаження на 1 га лісопарків Києва: $n=5,41$ люд. $\cdot$ дн. $^{-1} \cdot$ га $^{-1}$.

Наявну рекреаційну місткість $\left(E_{\phi}\right)$ розраховано шляхом множення середнього рекреаційного навантаження на 1 га на площу лісів, придатних для рекреації: $E_{\phi}=$ $5,41 \cdot 27805,6=150428$ люд./дн.

Використовуючи лісовпорядні дані розподілу площі лісів за класами стійкості та верхні границі норматив- них рекреаційних навантажень відповідно для другої та третьої стадій дигресії, за формулою (4) обчислено оптимальну $\left(E_{\text {onm }}\right)$ та граничну $\left(E_{2 p}\right)$ рекреаційну місткість лісопарків: $E_{\text {опm }}=84860$ люд./дн.; $E_{2 p}=254902$ люд./дн.

3 наведених вище розрахунків видно, що наявна фактична рекреаційна місткість лісопарків значно перевищує оптимальну, проте менша за граничну місткість. Результати розрахунків свідчать про високий природно-рекреаційний потенціал лісопаркових ландшафтів Києва.

Однією з причин перевищення рекреаційного навантаження на певних ділянках $є$ відсутність або недостатній рівень благоустрою деяких зон відпочинку. У період масового відвідування населенням лісопарків люди надають перевагу територіям з облаштованими місцями для пікніку, де $є$ мангали, лави, столи, урни та ін. Через те що не всі зони відпочинку належно облаштовані, відбувається нерівномірний розподіл відвідувачів по території лісопарку. Відповідно можемо спостерігати четвертий та п'ятий рівні дигресії живого надгрунтового покриву на одній зоні відпочинку, та другий чи перший на іншій, що $є$ прямим наслідком цього явища. Окрім цього, що зони відпочинку потрібно облаштовувати малими архітектурними формами, їх ще необхідно створювати у необхідній кількості. У разі невідповідності розмірів облаштованих зон відпочинку та кількістю 
охочих ними скористатись, виникає багато спонтанних місць відпочинку, котрі здебільшого облаштовуються відвідувачами на території лісопарку, не призначеної для цього. Окрім заподіяння значної шкоди живому надгрунтовому покриву та зеленим насадженням на цих територіях, $є$ також високий ризик виникнення низових пожеж.

Висновки. За результатами досліджень встановлено, що рекреаційне навантаження у досліджуваних зонах відпочинку близьке до оптимального та не перевищує гранично допустимого, а рекреаційна активність становить 86 год/рік. Отримані показники рекреаційних навантажень і рекреаційних місткостей дають змогу забезпечити та спланувати максимально раціональне та невиснажливе використання рекреаційного потенціалу лісопарків Києва. Результати розрахунку рекреаційної місткості свідчать про високий природно-рекреаційний потенціал лісопаркових ландшафтів Києва. Відповідно до результатів визначених фактичних рекреаційних навантажень у лісопаркових господарствах, потрібно застосовувати заходи, спрямовані на зниження рекреаційних навантажень в зонах масового відпочинку, їх збереження, ефективне використання та охорону територій, особливо у ділянках із третьою стадією дигресії і вище, оскільки виявлено тенденцію до збільшення рекреаційного навантаження за останні шість років. Також потрібно підвищити якість благоустрою територій, де є високий рівень рекреаційних навантажень.

\section{Перелік використаних джерел}

Bessonova, V. P., \& Zaytseva, I. A. (2016). Ontogenetic and vitality structures of the Acer Campestre L. and A. Tataricum L. ravine forest coenopopulations in conditions of recreational load. Scientific $\begin{array}{llll}\text { Bulletin of UNFU, 26(8), 185-193. } & \end{array}$ https://doi.org/10.15421/40260829

Hensyruk, S. A., Nyzhnyk, M. S., \& Vozniak, R. R. (1987). Recreational use of forests. Kyiv: Urozhai, 248 p. [In Russian].
Holubets, M. A. (2003). Modern problems of forestry. Scientific works of LANU, 2, 20-26. Lviv: NU "Lviv Polytechnic". [In Ukrainian].

Hordiienko, M. I., Maurer, V. M., Pinchuk, A. P., \& Ozadovskyi, V. V. (2007). The succession of living superficial cover of forest lands of Polissya and Forest-steppe. Scientific Bulleten of NAU, 106, 20 26. Kyiv. [In Ukrainian].

Ivaniuk, I. V. (2009). Bioecological peculiarities of planting technology of aesthetic forests in park management enterprises of Kyiv preurban zone. Candidate Dissertation for Agricultural Sciences (06.03.01 - Forest crops and Phytomelioration). Kyiv, 190 p. Retrieved from: V. Vernadsky National Library of Ukraine (ДС111313). [In Ukrainian].

Kovalevsky, S. B., Marchuk, Yu. M., Mayevsky, K. V., \& Kurdyuk, O. M. (2017). The scope and consequences of illegal amber extraction on lands of Zhytomyr RDFH. Scientific Bulletin of UNFU, 27(10), 69-72. https://doi.org/10.15421/40271011

Krasnov, V. P., Shelest, Z. M., \& Davydova, I. V. (2012). Phyto-ecology with the basics of forestry. Sumy: Universytetska knyha, 415 p. [In Ukrainian].

Kutia, M. M., \& Hirs, O. A. (2012). Characteristics of recreational load and recreational capacity of forest park landscapes of Kiev. Scientific Bulletin of UNFU, 22(12), 86-90. [In Ukrainian].

Maurer, V. M., \& Pinchuk, A. P. (2010). Successions of live ground vegetation as an integral evaluation criteria changes building forest lands and ecological forest events. Scientific reports of NUBiP, 5(21). [In Ukrainian].

Nevenchenko, A. I. (2015). Ecological and recreational development - important complex of optimization of the travel infrastructure of the carpathian region. Scientific Bulletin of UNFU, 25(5), 161164. Retrieved from: https://nv.nltu.edu.ua/index.php/journal/ article/view/1020. [In Ukrainian].

Population. (2012). The population of Kiev on July 1. Retrieved from: http://www.gorstat.kiev.ua/p.php3?c=1123\&lang $=1$

Population. (2018). Population (estimated) as of September 1. Retrieved from: http://www.kiev.ukrstat.gov.ua/p.php3?c=1123\&lang=1

Tarasov, A. Y. (1986). Recreational forest use. Moscow: Ahropromyzdat, 176 p. [In Russian].

Vozniak, R. R., \& Fukorevych, A. F. (2000). Method of determination of indicators of recreational characteristics and scope of recreational load and capacity of natural complexes. Irpin: UDPLVO "Ukrderzh-lisoproekt", 17 p. [In Ukrainian].

\section{LIVING GROUND COVER AS AN INDICATOR OF THE STATE OF FOREST PARK MASSIVES}

Living ground cover is the first link in the forest environment that suffers from an increased anthropogenic impact on it, therefore its status analysis is important in the study of recreational load in order to avoid and prevent irreversible destructive processes in biogeocoenoses. The main purpose of the work is to study and to determine the state of living ground cover in the recreational areas of Kyiv. To determine estimated features for recreational purposes and to calculate recreational loads and capacity of natural complexes we used the methodology proposed by R. R. Vozniak. We have identified that most recreation areas are characterized by the 2 nd and 3rd stages of the erosion on them. Besides the characteristic of herbaceous forest plants, the living ground cover has many representatives typical for meadows. However, due to the fact that not all the recreation areas are properly equipped and there is an uneven distribution of visitors through the territory of the forest park within the same recreation area, one can observe both the second and fifth stages of digression. This is especially noticeable where landscaping occupies a very small territory from its total area. In the course of a field observation of the recreation areas we determined the recreation coefficient and the recreational capacity. We also determined the actual recreational load on the test plots, corresponding to the optimal and maximum admissible loads for these areas. Out of four experimental areas, three had recreational loads close to the optimal and did not exceed the maximum admissible load; only one area had borderline recreational load indicator. We noticed the tendency of the recreational load to increase over the last 6 years. The existing actual recreational capacity of forest parks significantly exceeds the optimal, but is less than the marginal capacity which indicates the high natural-recreational potential of forest park landscape in Kyiv. The obtained indicators of recreational loads and recreational capacities allow providing and planning the most rational and non-exhaustive use of forest park recreational potential in Kyiv.

Keywords: stage of the digression; recreational load; recreation area; forest park coenosis; herbaceous plants. 